\title{
The Long Road to Partnership: Conflict Resolution of Register 45 Mesuji Lampung
}

\author{
Komang Jaka Ferdian ${ }^{1}$ \\ Hieronymus Soerjatisnanta ${ }^{2}$
}

\begin{abstract}
A known agrarian issue took place in Indonesia, particularly in the area of Register 45 Mesuji Lampung. The granting of natural forest management permit by the government to PT. Silva Inhutani, thus eliminating public access around Register 45 to manage the forest, subsequently lead to conflict in the region. The objectives of this research are, namely: 1) to explain the grounds for partnership in the Register 45 area; and 2) to analyze the partnership program undertaken in Register 45 as an effort of resolving conflict. This research used a descriptive qualitative approach that describes the results of research, assessment and other references reinforced with empirical data through interviews and observations. This study found a number of issues in the partnership agreement formation process, wherein the community was not being involved in the formation process of the partnership provisions, such as the planting process and the profit sharing scheme. The issues found in the implementation stage of the partnership agreement can be observed from an internal factor perspective, which was the unfulfilled expectation to increase acacia planting. Regarding the external factor, there were still many acts of thuggery in the area of Register 45 that interfered with the partnership process. There was also a fundamental problem in the partnership implementation, which was the prevalent lack of aptness in the mapping of community entitled to the partnership, as well as the lack of trust among collaborating parties.
\end{abstract}

\section{Keywords:}

land conflict; partnership program; interest; mediation.

\begin{abstract}
Abstrak
Permasalahan agraria di Indonesia terjadi di kawasan register 45 Mesuji Lampung. Konflik di kawasan Register 45 dipicu akibat adanya izin Hak Pengusahaan Hutan yang diberikan pemerintah kepada PT. Silva Inhutani sehingga menghilangkan akses masyarakat sekitar Register 45 untuk mengelola hutan. Tujuan dalam penelitian ini yaitu 1) Mengetahui dan menjelaskan penyebab timbulnya kemitraan di Register 45; dan 2) Menganalisis program kemitraan di Register 45 sebagai upaya resolusi konflik. Metode yang digunakan dalam penelitian ini adalah pendekatan deskriptif kualitatif yang menjelaskan hasil penelitian, pengkajian dan referensi lainnya diperkuat dengan data empiris yang dilakukan melalui wawancara dan observasi. Penelitian ini menemukan beberapa permasalahan dalam proses pembentukan perjanjian kemitraan yaitu tidak dilibatkannya masyarakat dalam proses pembentukan aturan kemitraan seperti proses tanam dan skema bagi hasil. Permasalahan pada tahap pelaksanaan perjanjian kemitraan dapat dilihat dari faktor internal yaitu tidak terpenuhinya harapan untuk meningkatkan tanaman akasia. Faktor eksternal yaitu masih banyak terjadi aksi premanisme di kawasan Register 45 yang mengganggu proses kemitraan. Permasalahan fundamental dalam pelaksanaan kemitraan yaitu belum tepatnya pemetaan masyarakat yang berhak mendapatkan kemitraan, serta belum adanya kepercayaan antar pihak yang bermitra.
\end{abstract}

\footnotetext{
1 Master of Political Science, Universitas Diponegoro, Semarang.

Email: komangjkf@gmail.com.

2 Faculty of Law, Univesitas Lampung.
} 


\section{Kata Kunci:}

konflik pertanahan; program kemitraan; kepentingan; mediasi.

\section{Introduction}

Forest management is an interesting issue for several actors particularly various communities and companies. Forest management in Indonesia bears social, economic, and political values. The interest of forest management will become vulnerable in the event of agrarian conflict involving the community and companies. Referring to the report published by the Agrarian Reform Consortium (KPA), agrarian conflict in Indonesia increased to 450 cases in 2016, whereas in 2015 merely 252 cases were observed. This hike in conflict shows that agrarian cases are susceptible to conflict.

The origin of agrarian conflict is essentially a fundamental problem. Throughout history it can be observed that man lived from being a hunter gatherer community to subsequently creating the innovation that is agriculture. In the life of hunter communities, the area where they hunt did not allow outsiders to enter. As is the case when man began to introduce farming, the area was restricted from entry by outsiders. This assumption consequently provides an illustration that control over an area cannot be claimed by other individuals or groups (of outsiders) (Wiradi, 2009, p. 3).

An instance of such agrarian conflict is one that occurred in the Register 45 Forest Area, in Mesuji, Lampung. The conflict concerning the Register 45 area had actually happened since 1986-1987 when the government conducted measurement of its boundaries. It was followed with eviction activities undertaken by the government in the forest area of Register 45 Sungai Buaya. This involved the North Lampung level II boundary team.

On the $7^{\text {th }}$ of October 1991, the government issued the Decree (SK) of the Ministry of Forestry No. 688/KPTS-II/1991, which afforded an Industrial Plantation Forest Management Permit (HPHTI) to PT. Silva Inhutani Lampung, Sungai Buaya Lampung. The extent of HPHTI given to PT. Silva Inhutani was as wide as 33.500 Ha. PT. Silva Inhutani is a joint company of PT. Silva Lampung Abadi and PT. Inhutani V.

In 1996-1997 a new residential area was established in the Register 45 area which consisted of communities from various regions. The residential area was known as Moro-moro. The arrival of communities into the Register 45 area was encouraged by three reasons, namely economic issue, community's need for land, and the community's envious sentiment toward the company. This sentiment is based on the fact that the HPHTI permit was given to the company while the community did not have any access to manage the Register 45 area.

Basically, PT.Silva Inhutani bears corporate social responsibility (CSR) in managing the Register 45 area. CSR refers to five main pillars of building human, strengthening economies, assessing social cohesion, encouraging good governance, and protecting the environment. One of the contributing factors to the conflict in area Register 45 is that in reality the company remained employing short termed perspectives and charity provisions in implementing CSR. Among the CSR programs conducted by company was distribution of daily necessities which in fact lead to the community becoming dependent on the assistance thus corroding social capital, local wisdom, and the community's independence. CSR implementation, basically charitable in nature, was unable to respond to the community's needs and did not provide the attention necessary. The lack of maximum efforts in conducting CSR had contributed to the spread of conflict in the area of Register 45. Neglect of CSR was basically a potential for conflict. The neglect consequently turned into 
a snow ball which had in fact exacerbated the conflict and made it become more extensive (Pujiriyani \& Oki, 2013).

The conflict in Register 45 has currently reached a scale of negative impact, in which security officers in the area perpetrated both direct and indirect violence. Direct violence occurred during an eviction in the area as shootings lead to two victims dead and wounded. Referring to the report compiled by the Joint Fact Finding Team (TGPF) ${ }^{3}$ the victim who died was Made Aste (38 yo) and the wounded victim was Nyoman Sumarte (32 yo) (TGPF Report on Mesuji, 2012).

Regarding indirect violence committed by the government, there was no civil registry residential documents made available and education rights was not fulfilled. Residential documents such as Identification Card (KTP), Family Registry (KK) and Birth Certificate were not provided to the community residing in the area of Register 45. They were also not afforded the rights to education, as the strong building established in the forest area of Register 45 had to be removed by the government. These two rights refer to constitutional rights that were not provided by the government (Wahab et al., 2013).

The conflict which occurred in Register 45 was merely between the community and the company. The community thought that they are entitled to manage the area of Register 45 although PT. Silva Inhutani possesses the concession for forest management. The conflict then had the potential to cause various new problems which would be disadvantageous to all parties. Based on the various issues above, left as it is the conflict would bring about negative

\footnotetext{
The team was formed through a decree of the Coordinating Ministry for Politics, Law, and Security Number Kep-64/MENKO/POLHUKAM/12/2011 dated $11^{\text {th }}$ of December 2011. The team was tasked to find relevant and accurate facts regarding all aspects pertaining to the legal occurrence which took place in the OKI Regency, South Sumatera and Mesuji Regency, Lampung.
}

impact to social life in the community. The government currently anticipates the spread of conflict by providing a conflict resolution which aims at a partnership between the company and the community using persuasive means or mediation. Based on those reasons, the research problems presented in this article are as follows:

1. What are the causes of partnership in the Register 45 Area, Mesuji, Lampung?

2. Why did the partnership program in Register 45, Mesuji, Lampung as an effort in conflict resolution experience problems?

\section{Research Methodology}

This research utilized a descriptive qualitative method to explore and understand individuals and groups in social life issues. Data was gathered from informants through a process of in-depth interview involving the offices of Lampung Provincial Forest Service, Mesuji Forest Service, Mesuji National Unity and Politics Agency, and residents of Register 45 Trubus/Baidi and Riko resident of Moromoro, as well as through document sources such as the Report of the Joint Fact Finding Team (TGPF) Mesuji 2012, Development Report of Register 45, MOU between the community and PT. Silva Inhutani Lampung, and Special Report on the Development of Encroachment Management and Partnership Plan in Register 45 Mesuji Lampung. Data analysis was conducted inductively in order to build an information of the general theme, then the researcher provided interpretation from the obtained data (Cresswell, 2009, p. 4).

\section{Map of Conflict in the Area of Register 45, Mesuji, Lampung}

The conflict in the Register 45 area was basically one of various dimensions, and orientation of economic interests. The actors involved in the conflict were not limited to the government, community of the Register 
Figure 1. Register 45 Map of Conflict Diagram

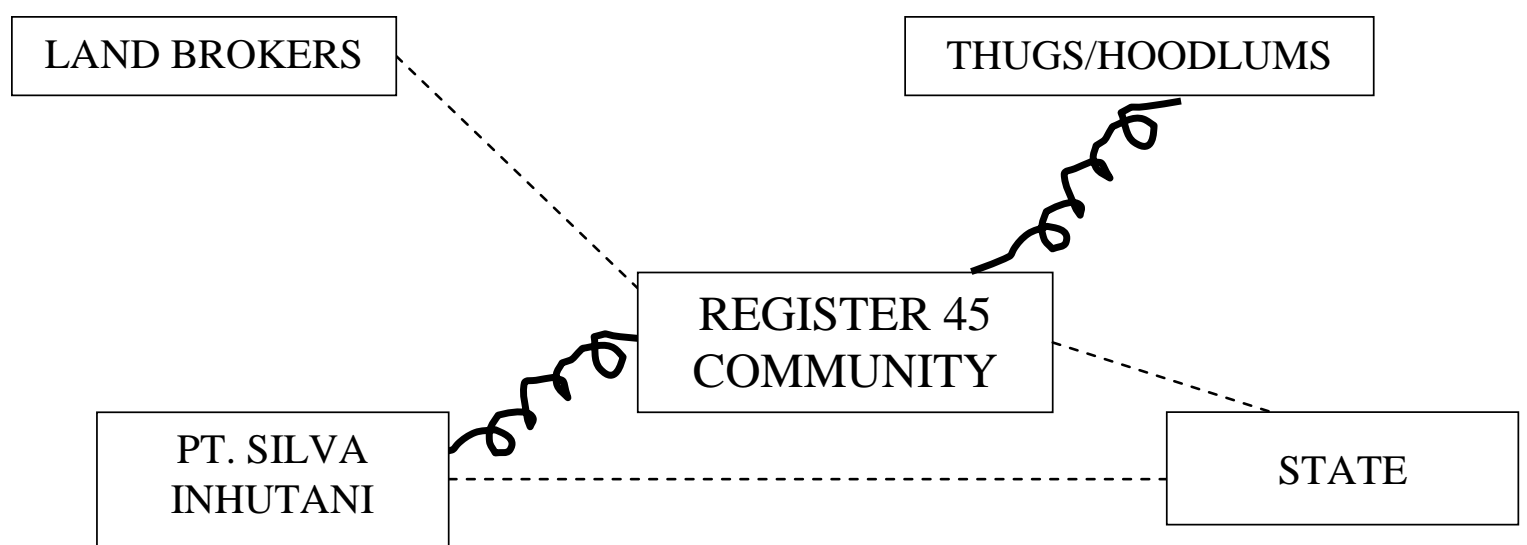

Information:

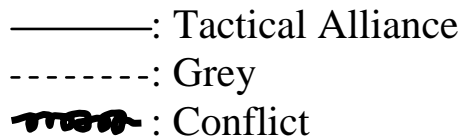

Source: data processed from the Joint Fact Finding Team (TGPF) Report on the Case of Mesuji 2012

45 area and PT. Silva Inhutani Lampung. The following is a map of conflict which illustrates the relationship between actors in the area of Register 45:

Regarding the conflict in Register 45, the community and PT. Silva Inhutani Lampung has a vertical conflict relationship. The conflict was triggered by the community's arrival into the area of Register 45. The reason for them entering into and cultivating the area was that the Register 45 area was abandoned from 1998 to 2004 and the 1998 economic crisis had also compelled them to move in to the area and undertake land cultivation. The large number of people coming into Register 45 had consequently limited the work area of PT. Silva Inhutani in managing the Production Forest Area. This is the reason brought forth by PT. Silva Inhutani for conducting evictions of houses in the Register 45 area which would subsequently lead to the conflict (Interview with Trubus Head of the Marga Jaya Group, on July $15^{\text {th }} 2016$ ).

The community and the state in Register 45 have a grey relationship in regards to the conflict. The government essentially disapproved people living in the area as occurring resistance cause various conflict to occur. Based on that rationale, the government conducted evictions, in collaboration with PT. Silva Inhutani, as a deterrent so the community no longer reside in the area, it, however, led to the death of Made Aste (38 yo) (Joint Fact Finding Team (TGPF) Report on Mesuji 2012).

The community and land brokers in the Register 45 area have a grey relationship. Both actors have economic interest regarding the matter. The community purchased land through brokers who divided the Register 45 area into land plots. They subsequently sold the land in that area with a price of 7.5 million rupiahs for 2 hectares. The land brokers offered the plot to the community based on the consideration of it being customary land. People who were unaware of the circumstances ultimately bought the plots of land. When they bought these plots in the Register 45 area, they were given documents stating that these are plots of customary land. This would further mobilize the rest of the community to buy land in Register 45 (Interview with Trubus Head of the Marga Jaya Group, on July $15^{\text {th }} 2016$ ). 
The community has a horizontal conflict relationship with the acts of thuggery committed in the conflict regarding the area of Register 45. The relation of the two actors was driven by economic interest. These acts of thuggery pertained to security money, wherein people living in the area are obligated to pay security fee to the hoodlum in that area. Those unwilling to pay the fee were threatened by use of violence (Interview with Riko resident of Moro-moro, on December 28 2016).

PT. Silva Inhutani and the state has a grey relationship regarding the conflict in Register 45. The relationship between the state and the company was indicated with inconsistencies in policy. These inconsistencies can be observed through the change in the extent of land area provided in the Forest Management Permit of PT. Silva Inhutani which had increased to 10,000 hectares. Additionally, PT. Silva Inhutani, by referring to the TGPF Report on Mesuji 2012, provided funding in the formation of an integrated team tasked with the eviction of communities residing in the Register 45 area.

\section{Pre-Partnership Conflict Resolution}

Agrarian issues throughout history has essentially been a political issue. Control over land has various interests which orientation leads to economic necessity. Politics in the field of land can be explained with the expression 'who has power'. Those possessing permit to control land would also control food thus potentially controlling life. Those in control of life would subsequently be in control of man (Christodoulou, 2009).

Agrarian conflict occurs because of four imbalances which are: imbalance regarding control of agrarian sources; imbalance in "function/use" of agrarian sources, particularly land; imbalance regarding agrarian perceptions and concepts; and imbalance of various legal products, as a result of pragmatism and sectorial policies. These four imbalances infuriated the community's thus leading to agrarian conflict in Indonesia (Wiradi, 2009, p. 3).

Regarding the conflict in Register 45, its roots can be further traced back to the period of 1986-1987, since the measurement of boundaries. Once boundaries were measured, the government on October 71991 issued a Ministry of Forestry Decree No. 688/Kpts-II/1991 stating that the Industrial Forest Plantation Management Permit is afforded to the company of PT. Silva Inhutani Lampung. This company is a combination of two companies, namely PT. Silva Lampung Abadi and PT. Inhutani V. The conflict was then caused by people entering the area of Register 45 to conduct land cultivation activities.

The conflict was reignited when the extent of Register 45 land had been broadened. On February 17 1997, the Forestry Minister issued Decree No. 93/Kpts-II/1997 on the provision of Industrial Forest Plantation Management Permit over a land area which was initially 33,500 hectares into 43,100 hectares. This addition of land area into Register 45 sparked a new conflict. The Talang Batin customary village community claimed that 2,600 hectares included in the additional land area is their customary land.

In 1998, a confrontation involving the Talang Gunung community and PT. Bangun Nusa Indah Lampung (PT. BNIL) occurred in the Register 45 area $^{4}$. The community was considered to have occupied a land area of 867 hectares. The confrontation led to the death of a security officer from PT. Silva Inhutani. This confrontation was triggered by people demanding the return of their village land included in the Register 45 Area. However, the government was adamant with the claim that the land in Register 45 be considered as state land, hence allowing PT. Silva Inhutani to manage that land area.

4 PT. BNIL is a subsidiary of PT. Sungai Budi Group which also includes PT. Silva Inhutani Lampung. 
PT. Silva Inhutani as the owner of the Industrial Forest Plantation Management Permit was ultimately unable to deal with an extensive land area of 43,100 hectares. The company was only able to manage approximately 17,000 hectares of land, with the remaining area being neglected as abandoned land and empty clearings. This is considered as a blessing by the Mesuji administration through the National Unity and Politics Agency by stating that the company is unable to manage all the land stipulated in the agreement. The company was at the time unable to manage the Register 45 area which induced them to collaborate with another company to plant other crop varieties which were pineapples and sugarcane. This led a notion which surfaced among the community that not only companies are allowed to manage the area but the community is also entitled to cultivate land in the Register 45 Area (Interview with the National Unity and Politics Agency of Mesuji Regency, July 15 2016).

The company's inability to manage the forest which ultimately results in abandonment of forest areas led community to enter the area of Register 45. According to Trubus, head of the Marga Jaya group, the people who trespassed into the Register 45 area were those in need of agricultural land in order to sustain their livelihood. They had entered into the area on basis of economic needs (Interview with the National Unity and Politics Agency of Mesuji Regency, July 15 2016).

All humans have a general hierarchy of needs which include basic necessities of food and shelter. Widjaja (2009: 30) stated that humans possess physical needs which must be fulfilled, namely feeling of safety, need to be wanted and loved, need for pride in power, freedom, prestige and others as well as the need for self actualization. Referring to this theory, the community in the Register 45 area occupied the land essentially to fulfill their physical needs thus compelling them to trespass into the Area of Register 45.

The community's entry into Register 45 was undoubtedly the fault of the company itself. Aside for being unable to manage the land area, PT.Silva Inhutani was also considered lacking in preventing people from trespassing. In the

Table 2.

The Wave of People Entering the Area of 45

\begin{tabular}{|c|c|}
\hline $\begin{array}{l}\text { Year of } \\
\text { Arrival }\end{array}$ & Explanation \\
\hline 1999 & The Talang Gunung community claimed 7,000 hectares of land area \\
\hline 2000 & The Labuhan Batin community group claimed 200 hectares of land \\
\hline 2001 & $\begin{array}{l}\text { Management of Register } 45 \text { production forest area (KHP) explained about existing encroachment into 4,000 } \\
\text { hectares of land by the Moro Seneng, Moro Dadi, Moro Dewe, and Sumber Agung groups }\end{array}$ \\
\hline 2006 & $\begin{array}{l}\text { The Suai Umpu customary group consisting of } 100 \text { individuals led by Sohir encroached into Division VIII, } \\
\text { the company received assistance from the Tulang Bawang Police Office (Polres) which did not last long } \\
\text { hence encouraging them to return to the Register } 45 \text { area. Additionally, the } 200 \text { men Tugu Roda group led } \\
\text { by Tohir encroached into locations in Division VII. }\end{array}$ \\
\hline 2007 & The Luwi group brought 800 people into the area of Register 45 . \\
\hline 2008 & $\begin{array}{l}\text { The Pekat nongovernmental organization began safeguarding the community groups thus increasing the } \\
\text { number of other community groups to manage the forest in Register } 45\end{array}$ \\
\hline 2009 & $\begin{array}{l}\text { The Pelita Jaya group led by Wayan Sukadana entered the area by bringing in } 300 \text { people into Division I. } \\
\text { The Karya Jaya group led by Yadi along with } 300 \text { people encroached into Division V. } \\
\text { The Karya Tani group led by Wayan Ana entered the region by bringing in } 200 \text { people into Division II. } \\
\text { The Suka Agung group led by Satir who holds the position as head of the Suka Agung Village brought } \\
200 \text { people into Division VIII. } \\
\text { The Megou Pak Tulang Bawang customary group led by Wan Mauli claimed that the land on Division } \\
\text { VIII is customary land. }\end{array}$ \\
\hline
\end{tabular}

Source: Special Report on the Development of Encroachment Management and Partnership Plan in Register 45 Sungai Buaya Mesuji Regency Lampung Province number 300/0951/II.03/2016 
agreement, the company has the obligation of protecting the forest from activities conducted by external parties. The security of the forest is therefore the purview of the company, and the government in this case has no obligation to help secure the forest. This lack in security ultimately led to the wave of people flooding into the area as recorded in the Development of Conflict in the Area of Register 45, Sungai Buaya, Mesuji Regency 2016, showed in table 2.

The large number of people inhabiting the Register 45 Area led to conflict which compelled the government to engage them in conflict resolution. A product of initial conflict resolution in Register 45 was the use of force through evictions. The government with support of the military was often an actor in the conflict in direct confrontation with the communities. The use of force is a stigma often observed when conflict is faced with a dead end and higher resistance from the grassroots (Wibowo et al., 2009, p. 65). The concept of violence covers a very broad range of aspect starting from acts of destroying goods/ belongings, battery, ritualistic destruction, and even manslaughter (Zubir, 2010, p. 21).

Evictions were conducted by an integrated team which consisted of the police, military and government. One was conducted in the Talang Gunung village in March 2010, wherein residential houses were demolished by heavy machineries. During the eviction none of the residents dared to fight back and the process went smoothly without any resistance from the community. They were forced to relocate and leave Register 45 which left them the option of scattering around the area. Some of them chose to stay with relatives living in the Mesuji area.

The conflict in the Register 45 area had reached the highest point of escalation as it led to acts of human rights violation. Referring to Karl Marx's concept, conflict occurs on the basis of struggle between two classes namely the bourgeois and the proletariat. The level of class struggle always reflects the dominant issue rather than social conflict. The struggle between the two classes exists on a Hegelian thesis and antithesis relationship meaning that one is signified by special ownership that the other lack (Muryanti et al. 2013, p. 10).

In the month of November 2010, the Lampung Province forest security team conducted eviction of shacks in the hamlet formerly known as Pelita Jaya. During the event, shots were fired by the integrated team unto Made Aste and Nyoman Sumarte. Both were taken to the Menggala General Hospital where Nyoman Sumarte's life was saved while Made Aste died upon arrival at the hospital (TGPF Report on Mesuji, 2012).

The death of Made Aste raised a number of speculations that it was a deliberate attempt. The government's reason for opening fire was afforded to the victim's acts which endangered the officers, wherein Made Aste was presumed to carry a machete during the eviction process. Referring to the fact finding investigation on the conflict of the Register 45 area Sungai Buaya, TGPF found an oddity in the death of Made Aste. The accusation that Made Aste had carried a machete was refuted by the TGPF report. The report stated that the officers had engineered the circumstances as video evidence found by TGPF showed Made Aste not carrying a machete at the time of shooting. The machete was placed after Made Aste had been shot.

In the month of February 2011, the integrated security team again conducted an eviction in the area of Register 45, but the community resisted by blocking the eastern cross road. As a result, the eviction activities were stopped because it disrupted the flow of traffic running on the eastern cross road. Nevertheless, several houses were already demolished by the integrated team.

The team attempted to approach the community once again and made several appeals expecting the community to cooperate and comply to the request of leaving the area 
of Register 45 on the 31sty of August 2011. If the community were to ignore the appeal, they would be forced to conduct evictions on the residents.

On the $8^{\text {th }}$ of September 2011, the integrated team had returned to exercise control over the Register 45 area by conducting evictions. The team employed approximately 60 personnel in the $\mathrm{D} /$ Pekat intersection area. The eviction brought down at least hundreds of homes in the time period of nine hours by using heavy machineries. They drove away the community and forced them to leave the area of Register 45. However, some of the people did not leave the forest area and evacuated to the Moro-moro region and some others went to the Sesat Agung traditional customary house.

The repressive conflict resolution ultimately brought about new conflict. The conflict which was initially caused by dissenting opinions, when resolved through violent means would only lead to even more difficult to control violence. The effect of that act of violence would, both directly and indirectly, instigate hostility from various parties. Conflict resolution through repressive means would lead to new conflict from the parties involved (Rombston et al., 2011, p. 16).

\section{Conflict Resolution through Mediation and Partnership}

A conflict unaddressed will bring about threat to one of the parties, a conflict issue initially specific in nature could expand to a global level, particularly when violence is employed by one of the parties (Pruitt \& Rubin, 2004, p. 12). The current concept of social conflict resolution does not use a repressive method but instead utilizes a persuasive approach. The government subsequently performed mediation in the effort of undertaking the persuasive approach. This refers to the concept stated by Johan Galtung that several institutions are necessary in order to diffuse conflict. The institutions responsible for conflict resolution namely are the government, NGOs, police/ military and customary figures/institutions. The above elements must work in accordance to these provisions: the conducts of Peacekeeping ${ }^{5}$ should be conducted by the police/military; the act of Peacemaking ${ }^{6}$ should be undertaken by the government to establish a mediator; and efforts in Peacebuilding 7 should be carried out by NGOs along with customary figures/ institutions (Austin, 2012, p. 59).

One of the programs undertaken to resolve conflict without the use of force was the Forest Partnership through Mediation Program. The lengthy conflict in Register 45 had finally been resolved through the use of mediation among stakeholders. Mediation in the area of Register 45 Sungai Buaya was undertaken by the government with the objective of diffusing conflict in order not to repeat the escalation of conflict which ended in the use of violence against the community in Register 45. The government led mediation involved several stakeholders, among them were the community of Register 45, the government, the police, and PT. Silva Inhutani. The mediation ultimately brought about the Forest Partnership Program.

The partnership in the Register 45 area was established based on a number of regulations which provided support to the success of the partnership. The legal basis in the implementation of forest partnership in the Register 45 area employed three regulations. First, the regulation included in the partnership program, that is the Ministerial Decree Number 93/kpts-II/1997 on the provision of Industrial

\footnotetext{
5 Peacekeeping is the act of keeping security conducted by the police/military to suppress the expansion of conflict.

6 Peacemaking is acts performed by peacemakers through the use of diplomatic efforts to end violence among conflicting parties by using the strategy of mediation in diffusing conflict.

7 Peacebuilding is acts conducted by peace builders (NGOs/communities) with the objective of promoting the achieved peace as well as address violence found in the community.
} 
Forest Plantation Management Permit over a Forest Area of 43,100 hectares in the Province of Lampung to PT. Silva Inhutani. This decree was used to emphasize that the holder of the Industrial Forest Plantation Management Permit is PT. Silva Inhutani.

The second regulation is the basic regulation on the partnership itself. The Forest Ministerial Regulation No. 39 year 2013 on Empowerment of Local Communities through Forest Partnership is the basis for partnership programs in Indonesia. This policy was established to develop and specially to provide access for the community to collaborate with companies in forest management. This regulation provides explanation on the establishment procedures and lists the principles necessary for a partnership program.

The final regulation referenced in the forest partnership is the Forest Ministerial Regulation No. 12 Year 2015 on the Spatial Development of Production Forest Plantation. This regulation contains principles in developing Industrial Forest Plantation. The development process involves planting patterns and appropriate crops to be developed in the Industrial Forest Plantation area. It is also stipulated in the regulation that the company in the Industrial Forest Plantation is to be used for planting staple crops, life crops and conservation area. The main crop is to be planted to at least $70 \%$ of working area, while life crops are at least $20 \%$ of working area.

The chronology leading up to the partnership in Register 45 Sungai Buaya, Mesuji, Lampung can be seen in the table 3.

The agreement achieved through the mediation to discuss the Partnership $\mathrm{MoU}^{8}$

\footnotetext{
${ }_{8}$ Memorandum of Understanding (MoU) is a legal action conducted by one of the parties declaring its intent to another party regarding an offer. A Memorandum of Understanding is also a joint agreement based on prevailing law or existing regulation. This agreement involves two or more parties arranging it, in which they are afforded the
}

Table 3.

Chronology of Partnership in the Register 45 Area Sungai Buaya

\begin{tabular}{cl}
\hline Year & \multicolumn{1}{c}{ Activities } \\
\hline 2014 & $\begin{array}{l}\text { Discussion of partnership concept with } \\
\text { stakeholders involved in the Register 45 area, } \\
\text { dissemination to the communities, drafting of } \\
\text { initial agreement. }\end{array}$ \\
\hline 2015 & $\begin{array}{l}\text { Discussion through coordinative meetings, } \\
\text { public dissemination, community mapping, } \\
\text { signing of agreement, training for learning forest } \\
\text { cultivation techniques. }\end{array}$ \\
\hline 2016 & $\begin{array}{l}\text { Implementation of pilot partnership involving } \\
\text { communities in Marga Jaya, Sido Rukun, Karya } \\
\text { Jaya, Maju Jaya, Tugu Roda, Mekar Jaya and } \\
\text { Karya Tani. }\end{array}$ \\
\hline
\end{tabular}

Source: Information Handbook KHP Register 45 Sungai Buaya Mesuji 2016

in the area of Register 45 between PT. Silva Inhutani Lampung and the community resulted in a number of agreements. The establishment of this collaboration is meant to rehabilitate the production forest area of Register 45 Sungai Buaya Mesuji Lampung which is intended for the exploitation of forest timber product in industrial forest plantation (HPHTI) through a forest partnership scheme along with the communities residing in and around the forest area. Its goal is to realize sustainable forest production management in the forest production area of Register 45 Sungai Buaya Mesuji Lampung by empowering local communities directly thus providing economic, social and environmental benefit for the license holder, community, and state.

The scope of this partnership agreement covers crop type, cost and profit sharing, period of partnership and conflict resolution?. Article 3 (three) of the MoU stipulates that the plant cultivated for the forest partnership be a staple wood crop of acacia and an annual

opportunity to initially conduct a feasibility study in order for the agreement to be detailed, thorough and ultimately binding the parties involved.

9 Memorandum of Understanding between PT. Silva Inhutani Lampung and Sido Rukun Community Group No: 006/Sil-MoU/IX/2015. No: 001/SR/IX/2015 
crop of cassava which is in accordance to laws and regulations on spatial planning and work plan. The planting cost is the responsibility of PT. Silva Inhutani Lampung while the planting itself is conducted by the community. The implementation of planting staple wood crop is to be $20 \%$ of cultivated land, and it must be annually increased by $20 \%$ from the remaining cultivated land.

The planting pattern employed for the Marga Jaya area was intercropping. This was conducted as such because the Marga Jaya group desired land uniformity wherein all its members must cultivate $20 \%$ acacia which shall be accounted for by each group member. The disadvantage of the intercropping pattern employed by the Marga Jaya group lies during the cassava growth period when they have become taller and during the cassava harvest period. Plants need the sun to survive, the intercropping pattern implemented by the partnership was to plant acacia along with cassava, when the cassava matures and gains taller, it will consequently obstruct the growth of the acacia by limiting its access to sunshine. Thus, ultimately the cassava plant hinders the growth and development of the acacia plant.

In addition to that, cassava harvest also bore damaging effect on the acacia. According to the Lampung Province Forest Service, they observed quite a number of acacia plant damaged during cassava harvest season. This is because the process of harvesting cassava was done by pulling its roots out of the ground causing other plants in the surrounding area to be rooted out as well. This harvest method subsequently damaged acacia plants growing next to the cassavas. (Interview with the Lampung Province Forestry Service, January 10 2017)

Another group used the block planting method which was carried out to achieve maximum production for both acacia timber and annuals that were managed collaboratively and was shared according to the members' ownership based on verification results. This method was favored by the groups with the consideration that it is easier in its on field implementation and monitoring.

The block planting method has an advantage in its planting pattern, wherein the cultivators does not plant the crops side by side or next to each other but by way of putting them in groups. The acacia plants are placed in a different area from the cassava plant. This will then provide space for growth and development of the respective plant. The planting target of the respective group is as follows:

Table 4.

Data of the KHP group in the MoU with PT. Silva Inhutani

\begin{tabular}{cllr}
\hline No. & Partner Group & $\begin{array}{c}\text { Head of } \\
\text { Group }\end{array}$ & $\begin{array}{c}\text { Land Area } \\
\text { (Hectare) }\end{array}$ \\
\hline 1 & Marga Jaya & Trubus & 342 \\
2 & Karya Jaya & Patmono & 2,190 \\
3 & Karya Tani & Sunoto & 1,100 \\
4 & Maju Jaya & Jarno & 680 \\
5 & Tugu Roda & Yasin & 250 \\
6 & Sido Rukun & Syaifulloh & 290 \\
7 & Mekar Jaya & Sobrin & 1,400 \\
\hline \multicolumn{3}{c}{ Total } & $\mathbf{6 , 2 5 2}$ \\
\hline
\end{tabular}

Source: Special Report on the Development of Encroachment Management and Partnership Plan in Register 45 Sungai Buaya Mesuji Regency Lampung Province number 300/0 0951/II.03/2016.

The profit sharing scheme applied refers to article 3 verse 4 letters $a$ and $b$ of the MoU on Partnership in Register 45, wherein crop yield will be deducted by capital which the company spent. Once net profit is obtained, meaning that initial capital spent by the company has been deducted from the gross profit, PT. Silva Inhutani receives $75 \%$ share while the community gets $25 \%$ share from the profit of planting the staple wood crop of acacia. As for planting cassava, both PT. Silva Inhutani and the community receive $50 \%$ equal shares once the cost of capital has been deducted from the gross profit. 
The period of the MoU as stipulated in the agreement is decided to become effective on the date of the signing by the parties involved. The parties concurred that the agreement be implemented up to 1 (one) cycle of staple wood crop harvest period (more or less 6 years) and it can be extended in accordance to the agreement of parties involved. Conflict resolution among parties has also been agreed upon and stipulated in the MoU. Article 6 states that if conflict were to occur regarding the interpretation or implementation of provisions stipulated in the partnership agreement in the future, the parties have agreed to resolve the issue through deliberations aimed at reaching a consensus. If a consensus cannot be reached, legal procedures in accordance to existing laws and regulations would subsequently be taken in order to appropriately resolve the conflict. (MoU PT. Silva Inhutani and the Community No. 004/Sil-MoU/IX/2015)

\section{Criticism on the Partnership Program in the Area of Register 45 Mesuji Lampung}

The partnership in the area of Register 45 is currently in its implementation stage. The partnership which involves the community and PT. Silva Inhutani aims to harmonize relationship between PT. Silva Inhutani and the community in the Register 45 forest area. The partnership was achieved through persuasive means, namely mediation which emphasized on the principle of common good.

According to on field observations, the current partnership implemented in Register 45 encountered various problems from the formation of the partnership MoU, the implementation of the partnership $\mathrm{MoU}$, up to fundamental issues. These three problems emerged because there were various group interests involved.

The issue in the formation of partnership in the Register 45 Area began from the mediation process. Essentially, mediation functions as a channel to express the opinions of conflicting parties so that a bargaining process can take place and an agreement can ultimately be reached. The bargaining process will eventually reduce the presence of conflicting parties/ arguments and ultimately all aspirations of the parties involved would have been fulfilled. The parties must elaborate on the problems they experience, these problems from the respective party will then be gathered and analyzed into a single concept and consequently producing a win-win solution (Davidson \& Wood, 2004).

The state facilitated the mediation of partnership formation by getting the community and PT Silva Inhutani Lampung to sit together in order to reach a mutual agreement. According to the Mesuji Forestry Service, PT. Silva Inhutani determined the content of the partnership MoU. Once the MoU draft had been prepared, the company gave the draft to the government to be reanalyzed. The community at this stage of the process was not involved, they only accepted the provisions stipulated in the partnership agreement provided by PT. Silva Inhutani (Interview with Mesuji Forestry Service, July 16 2016).

The role of the community in the mediation process was very minimal, they did not participate in determining the scheme for profit sharing. The company made the agreement independently, they made regulations to plant wood crop and annual crop. In this particular case, the chosen wood crop was acacia and the annual crop cassava. The mediation did not run as it should because the resulting agreement favors the company more. The community is relegated to become workers as they would receive wages from the crop yield once it is deducted by capital cost the company had spent.

The objective of investors in siding with public interest is merely a guise to seek profitability. The main objective of investors is really to seek profitability. They will camouflage themselves with public interest to achieve their own interests. Investors consider that public 
interest will be more effective in comparison to operating on their own. At the end of the day, they do not have the desire to advance public interest as they only seek profit for their own interest (Smith, 2007, p. 14).

The issue in partnership implementation was found in both internal and external factors. The problem in the internal factor was that the agreement was not implemented as stipulated in the partnership. The planting of cassava obstructed the acacia plants during maintenance. Regarding external factor of the partnership, security breach continued to occur which interfered with the ongoing process of partnership.

During the first stagein theimplementation of the partnership program, the total land area prepared by the company for partnership was 6,250 hectares and the community only focused on planting cassava rather than planting acacia. The community was able to plant as much as 216.3 hectares of cassava, yet they were only able to plant 47.9 hectares of acacia. The reason for this is that the planting cycle for cassava is faster compared to that of acacia. Based on that reasoning, the community prefers cassava over acacia. The following table shows the quantity of cassava planting being higher than that of acacia:

Table 5.

Development in Partnership Implementation

\begin{tabular}{|c|c|c|c|}
\hline \multirow{2}{*}{ No } & \multirow{2}{*}{ Partner Group } & \multicolumn{2}{|c|}{ Crop Type } \\
\hline & & Cassava & Acacia \\
\hline 1 & Marga Jaya & 23.2 & 7.4 \\
\hline 2 & Karya Jaya & 58.15 & \\
\hline 3 & Karya Tani & 11 & \\
\hline 4 & Maju Jaya & 29,6 & \\
\hline 5 & Tugu Roda & 29.15 & \\
\hline 6 & Sido Rukun & 49.2 & 33 \\
\hline 7 & Mekar Jaya & 16 & 7.5 \\
\hline & Total & 216.3 & 47.9 \\
\hline
\end{tabular}

Source: Special Report on the Development of Encroachment Management and Partnership Plan in Register 45 Sungai Buaya Mesuji Regency Lampung Province number 300/0 0951/II.03/2016.
Another factor contributing to the small quantity of acacia planting in the partnership implementation is the planting method given to the community. One of the planting methods used is intercropping which could damage the acacia plant. Acacias which were planted in close proximity to cassavas will be rooted out when cassava is being harvested. The process of harvesting cassava is carried out by pulling out its roots which subsequently damages the surrounding crops. Acacia will be unable to grow properly once it has been pulled out and the roots left in the ground.

The lack of acacia planted in the partnership implementation can be construed as a form of community opposition to the investors. This opposition takes the form of rebellious resistance demonstrated by the forest farmers. According to Sulistiyaningsih, the form of rebellion farmers demonstrate is by deliberately killing the staple crop, they intentionally disobeyed the planting regulation. This is conducted merely to create a safety net of food reserve, bearing in mind that the assets or area of management they possess are relatively small (Sulistyaningsih, 2013, p. 6).

The external factor which obstructs the implementation of the partnership program is the hindrance brought about by acts of thuggery. According to Dahrendorf, there are two groups involved in a conflict, they are the quasi group and the interest group. The quasi group is a gathering of authorities or power players with the same interest that is formed by the advent of interest groups. The interest group is formed from a broader catch-all groups, and it has a structure, organization, program, objectives and dedicated members (Muryanti et al., 2013, p. 23).

The acts of thuggery found in the area of Register 45 were committed by quasi groups having authority over Register 45 lands illegally. They put pressure on interest groups namely the community participating in the Register 45 partnership program not to adhere 
to the partnership. These acts of thuggery in controlling land area of Register 45 became an obstructing factor in the implementation of partnership in Register 45. Many community group members remain left without any land as land areas provided to be managed by the community has been controlled by thugs/ hoodlums. Additionally, the areas meant to be managed under the partnership already had plants growing on them, thus discouraging the community to plant in those areas.

Due to the prevalence of security breaches, the community undertook more mediation relating to that issue. The mediation was facilitated by the government who sat PT. Silva Inhutani with the community on the $28^{\text {th }}$ of July 2016 . The government institution serving as mediator was the police and Mesuji Forestry Service. The result of the mediation was that the company will be responsible to maintain security with optimum efforts. As for the police, they will only be present for additional assistance, the police will response if there is a report from the company regarding interference by thugs/hoodlums or other security breaches in the area.

The fundamental issues being neglected in the partnership is that no mapping of communities entitled to partnership is made available, and that there is still a lack of trust among the parties involved in the partnership. In the partnership program, the mapping of communities entitled to take part in the partnership remains inappropriate. The communities involved in the partnership are those who have just resided in the area of Register 45 from 2010 to 2013.

According to the Ministry of Environment and Forestry Regulation No. 39 year 2013, the communities entitled to take part in partnership are communities residing in or around the forest as proven with an ID card or letter of residence from the local village head. The forest community means the communities residing in the area of Register 45 who are located in
Mesuji. By observing the Mesuji partnership, it is known that the communities taking part in the partnership are new communities that are not originally from the Mesuji Regency, and this can be taken advantage of by certain culprits in terms of land management.

An inappropriate mapping will lead to another conflict relating to aspects of social jealousy. The original communities of Mesuji, prior to the advent of forest encroachment in that area did not dare to enter the forest area and cut down trees as there are strict enforcement of prohibition in cutting trees. The regulation discouraged the community to encroach into the Register 45 area. Several years later, particularly after the 1998 reform and the addition of Register 45 land area conducted by the government, the community claimed the customary land that was included into the area. This sparked the activities of forest encroachment and land claims which consequently impacted on land trade in the Register 45 area. As sales of land became widespread, many people originally from outside the Mesuji region began entering the area. This is the cause of conflict which ultimately led to the implementation of the partnership.

The original settlers in Mesuji will in effect be jealous as they do not take part in the partnership program from the government although they reside in the Mesuji regency. This social jealousy emerges and will as a consequence lead to horizontal conflict among Mesuji communities and newcomers settling in the Register 45 Area. Thus, it of utmost importance to conduct community mapping based on the principles provisioned in the Ministry of Environment and Forestry Regulation No. 39 year 2013.

Another fundamental issue left unaddressed by the government is trust among parties. The Ministry of Environment and Forestry Regulation No. 39 year 2013 Article 5 letter e states that forest partnership be established based on mutual trust of parties 
involved. Trust becomes a fundamental value in the implementation of collaborative partnership.

Distrust will rouse suspicions which will eventually disrupt partnership relations. For instance, when the community constantly feels being deceived, they will not wholeheartedly implement the agreement which has been mutually agreed upon. Therefore, the government needs to establish trust among the two parties in order for them to collaborate effectively. The trust established by both parties will create good partnership that contributes to the success of the partnership program.

It is observed that the partnership in the Register 45 Area has yet to show trust established between the community and PT. Silva Inhutani. The community is of the opinion that the mediation on partnership is full of convolutions and intrigues from the company. The mediation has been conducted for almost a year now and it has been carried out more than ten times without achieving any results at all. The community was merely given theories on partnership, this led the community to perceive that there are intrigues employed by the company in the partnership program (Interview with Trubus, Head of the Marga Jaya group, July 15 2016). Based on the above, suspicion remains to be found among one of the parties involved which subsequently becomes an obstacle to the implementation of the partnership program.

\section{Conclusion}

The conflict in the Area of Register 45 is a latent conflict which dates back to the period before the 1998 reform. The conflict had reached the highest conflict escalation signified by the occurrence of direct and indirect violence. The direct violence observed in the conflict was the public shooting committed by the government officers. As for indirect violence, there was neglect of public constitutional rights. These issues ultimately compelled the government to implement a partnership.
Partnership in the Register 45 Area is yet to be considered fully successful. Many problems and issues remain to be found. Problems relating to the formation process, the implementation as well as unfinished fundamental issues. The problem in the formation stage refers to the lack of community involvement in the drafting of the agreement between the company and the community. As for the problem in the implementation stage, it relates to both internal and external factors that could potentially impede partnership implementation. Lastly, there are unfinished fundamental issues remaining, namely, the mapping of communities entitled to take part in the partnership program and the lack of trust among parties involved in the partnership.

\section{References}

Austin, B. (2012). Berghof, Glossary on Conflict Transformation. Berlin: Berghof Foundation.

Christodoulou, D. (1990). The Unpromised Land, Agrarian Reform and Conflict Worldwide. London and New Jersey: Zed Books.

Creswell,J.W.(2009). Research Design: Qualitative, Quantitative, and Mixed Methods Approaches. California: SAGE Publications.

Davidson, J., Christine W. (2004). A Conflict Resolution Model. Conflict Resolution and Peer Mediation Journal, 43(1), 6-13.

Direktorat Jenderal Perhutanan Sosial dan Kemitraan Lingkungan. (2016). Special Report on the Development of Encroachment Management and Partnership Plan in Register 45 Sungai Buaya Mesuji Regency Lampung Province number 300/0 0951/II.03/2016. Retrieved September 30, 2016 from http:// www.menlhk.go.id/tinymcpuk/gambar/ file/Kemitraan\%20Tahun\%202015.pdf.

Kronologis Kasus Register 45 Way Buaya Mesuji Lampung. (2011). Retrieved September 22, 2014, from http://www.beritasatu.com/ ekonomi/21963-kronologis-kasus-register45-way-buaya-mesuji-lampung.html. 
Muryanti, Damar D.N., \& Rokhiman (2013). Teori Konflik dan Konflik Agraria di Pedesaan. Yogyakarta: Kreasi Wacana.

Oki Hajiansyah Wahab. (2013). Gerakan Aktif Tanpa Kekerasan: Sebuah Transformasi Perjuangan Masyarakat Kasus Masyarakat Moro-Moro Register 45 Mesuji Lampung. Jurnal Ilmu Sosial dan Ilmu Politik, 16(3), 217-233.

Pruitt, Dean G., dan Jeffrey Z. Rubin. (2004). Teori Konflik Sosial. Yogyakarta: Pustaka Pelajar.

Pujiriyani, Dwi Wulan, dan Oki Hajiansyah Wahab. (2013). Kemandegan CSR dan Kontribusinya terhadap Perluasan Konflik Agraria di Kawasan Hutan Register 45 Mesuji. Jurnal Ilmu Sosial dan Ilmu Politik. 17(2), 101-115.

Rombston, Oliver, at al. (2011). Contemporary Conflict Resolution: The Prevention, management and transformation of deadly conflicts. Cambridge: Polity Press.
Smith, Adam. (2007). An Inquiry Into The Nature And Causes of The Wealth Of Nations. New York: MetaLibri.

Sulistyaningsih. (2013). Perlawanan Petani Hutan (Studi atas Resistensi Berbasis Pengetahuan Lokal. Yogyakarta: Kreasi Wacana.

Tim Gabungan Pencari Fakta. (2012). TGPF Temukan Pelanggaran HAM. Retrieved from http://www.pikiran-rakyat.com/ node/171591.

Wibowo, L. R., Woro M. R. \& Subarudi. (2009). Konflik Sumber Daya Hutan dan Reforma Agraria: Kapitalisme Mengepung Desa. Yogyakarta: Palma Foundation.

Widjaja, Bernard T. (2009). Lifestyle Marketing. Jakarta: PT. Gramedia.

Wiradi, Gunawan. (2009). Reforma Agraria Perjalanan yang Belum Berakhir. Yogyakarta: STPN Press.

Zubir, Zaiyardam. (2010). Budaya dan Jaringan Kekerasan. Yogyakarta: INSIST Press. 